\title{
The Role and Impact of E-Marketing in Improving Rural Tourism in Osijek- Baranja County
}

Preliminary communication _ DOI 10.22522/cmr20200157__received on 28 October 2019

UDK: $338.48-6: 711.3$

658.8:004

. . . . . . .

\section{Marija Završki, PhD Candidate}

The Doctoral School of the Josip Juraj Strossmayer University of Osijek, Osijek, Croatia. E-mail: zavrskim@gmail.com

\section{Katarina Horvat, PhD Candidate}

The Doctoral School of the Josip Juraj Strossmayer University of Osijek, Osijek, Croatia.

E-mail: katarina.horvat@horka.hr

\section{Abstract}

The increasing role of e-marketing in the tourism industry has affected and developed communication of all involved stakeholders - inhabitants, tourist workers and many influential groups. They all participate in the creation of the infrastructure in a manner that helps develop tourism. Continental tourism in Croatia begins to develop more intensively, while tourism in Slavonia, Baranja and Srijem has significant potential to develop the tourism identity of the eastern region. A key role in the promotion of destinations in Slavonia for domestic and foreign guests on the Internet is played by e-communities consisting of stakeholders from the public and civil sectors, tourist boards, local self-government units, professional tourism associations and local family farms offering tourism services. This paper deals with the influence of the holder of the function of tourism development and the management of the image of the tourism offer in the e-sphere, while the accompanying research is based on a combination of the theoretical approach and empirical data, and represents a way in which these entities combine and cooperate in shaping the umbrella marketing concept of promotion of the tourism offer in Slavonia.

Keywords: Slavonia, rural tourism, development, e-marketing, cluster

*Sadržaj rada temelji se na osobnim stavovima autorice i ne odražava stav Hrvatske gospodarske komore. 


\section{Uloga i utjecaj e-marketinga u turizmu Slavonije i Baranje}

Prethodno priopćenje_DOI 10.22522/cmr20200157_primljeno 28. listopada 2019.

UDK: 338.48-6:711.3

658.8:004

\section{Marija Završki, doktorand}

Doktorska škola Kulturologije, Sveučilište Josipa Jurja Strossmayera u Osijeku, Osijek, Hrvatska.

E-pošta: zavrskim@gmail.com

\section{Katarina Horvat, doktorand}

Doktorska škola Kulturologije, Sveučilište Josipa Jurja Strossmayera u Osijeku, Osijek, Hrvatska.

E-pošta: katarina.horvat@horka.hr

\section{Sažetak}

Sve veća uloga e-marketinga u turizmu utjecala je na razvoj međusobne komunikacije lokalnog stanovništva, posebice u ruralnim destinacijama i turističkih djelatnika. Oni zajedno participiraju u stvaranju infrastrukture na način koji im pomaže u poboljšanju razvoja turizma. Kontinentalni se turizam u Hrvatskoj počinje intenzivnije razvijati, a turizam u Slavoniji, Baranji i Srijemu ima izražen potencijal za razvoj turističkog identiteta istočne regije. Ključnu ulogu u promociji destinacije Slavonije za domaće i strane goste na internetu imaju posebne e-zajednice koje čine dionici javnog i civilnog sektora, turističke zajednice, jedinice lokalne samouprave, stručna udruženja u turizmu i lokalna obiteljska gospodarstva s djelatnošću u turizmu. Ovaj se rad bavi utjecajem nositelja funkcije turističkog razvoja i upravljanjem imidža turističke ponude u e-sferi, a popratno istraživanje temelji se na kombinaciji teorijskog pristupa i empirijskih podataka i predstavlja način na koji ti subjekti kombiniraju i surađuju u oblikovanju krovnog marketinškog koncepta promocije turističke ponude u Slavoniji.

Ključne riječi: Slavonija, ruralni turizam, razvoj, e-marketing, klaster 


\section{Uvodna razmatranja - Gdje je Slavonija u domaćem turizmu?}

Slavonija bilježi kontinuirani rast broja domaćih i stranih gostiju, a proporcionalno tome sve su veća ulaganja u razvoj sveukupnog turističkog potencijala, odnosno infrastrukture, što se prvenstveno odnosi na proširenje smještajnih kapaciteta, razvijanje turističke ponude, aktivnosti i turističkih sadržaja $u$ istočnom dijelu kontinentalne Hrvatske, te $u$ jačanje marketinške koncepcije $u$ kontekstu pozicioniranja u domaćem gospodarskom sektoru. Shodno tome, ulaže se u konačni proizvod - brendiranje regionalnog turističkog identiteta destinacije Slavonije. Prethodna istraživanja upućuju na intenziviranje ulaganja u razvojnu strategiju hrvatskog turizma, gdje upravo Slavonija, Baranja i Srijem posjeduju sve (tražene) atribute i za razvoj prepoznatljivog turističkog brenda na međunarodnoj turističkoj karti. S ciljem povećanja regionalne prepoznatljivosti i strateške marketinške koncepcije, pet slavonskih županija (Osječko-baranjska kao najveća s društveno-gospodarskim središtem u Osijeku, a koju po veličini slijede Brodskoposavska, Vukovarsko-srijemska, Virovitičko-podravska i Požeško-slavonska) obuhvaćeno je jedinstvenom strategijom razvoja. Sveobuhvatnom zajedničkom razvojnom strategijom pet je županija polovicom 2018. godine apostrofiralo sporazum o suradnji i uopćavanju marketinških segmenata $u$ jedinstvenu i prepoznatljivu turističku destinaciju s jasno pozicioniranim imidžem Slavonije i Baranje kao perjanicom ruralnog turizma.

Riječ je o sporazumu Ministarstva turizma i navedenih županija koji obuhvaća aktivnosti izradestrateškihmarketinških dokumenata namijenjenih zajedničkojpromociji Turističkog klastera Slavonije u razdoblju od 2019. do 2025. godine. ${ }^{1}$ Svaka županija, naznačeno je ponaosob, nastavlja neometano promovirati svoje turističke posebnosti - atrakcije, baštinu i lokalnu etno tradiciju kojom konkurira u domaćem turističkom okruženju. Međutim, $u$ kontekstu šire razvojne strategije ruralnog turizma, odnosno turističkih aktivnosti koje se odvijaju u ruralnom području manifestirajući se kroz selektivne oblike agroturizma, cikloturizma, gastroeno turizma i dr., turistička ponuda svih promatranih županija dijeli slične karakteristike koje se mogu umrežiti u supramarketinšku koncepciju koja bi u svojoj misiji sadržavala submarketinške koncepcije svake županije pojedinačno. Takva izgradnja i upravljanje marketingom u skladu je s politikama vođenja destinacije kao jedinstvenog

1 Strategija marketinškog plana turizma Slavonija s planom brendiranja za razdoblje 2019. - 2025. Turizam Požeško-slavonske županije. Dostupno na: https://tzzps.hr/novosti/strategija-marketinskog-plana-turizma-slavonija-s-planom-brendiranja-za-razdoblje-2019-2025-g/. Pristupljeno 21. kolovoza 2019. 
društveno-kulturnog prostora kao postojanog turističkog brenda. Na tom su polju već učinjeni prvi zahvati.

Tim stručnjaka s Instituta za turizam izradio je radni prijedlog projekta promocije za pet slavonskih županija te krovnu strategiju brendiranja čitave regije, a projekt je predstavljen slavonskim turističkim djelatnicima. Također, u Osijeku i diljem Slavonije održani su prvi Dani hrvatskog turizma u listopadu 2019., a gdje je u fokusu bio razvoj kontinentalnog, a time i ruralnog turizma na istoku Hrvatske.

\subsection{Teorijski okvir}

Odnosom ruralnog turizma, destinacije i marketinga, u stranim se teorijskim razmatranjima desetljećima bave renomirani autori (Buhalis, 2003; O’Connor, 1999), koji ICT tehnologiju vide kao važan generator u strateškom razvijanju ruralnog turizma i sadržaja na takvim područjima. U tom kontekstu teorije destinacijskog menadžmenta, sukladno ubrzanom razvoju ICT tehnologija i digitalnog marketinga, nezaobilazne su u proučavanju utjecaja interneta na turizam i obrnuto (Andrlić, 2007; Bolfek, Lončarić, 2013). U proteklom desetljeću reprezentativni su radovi domaćih znanstvenika, koji osim u znanstvenoistraživačkom radu, sudjeluju u izradi projektnih planova razvoja i unaprjeđenja više ruralnih destinacija s područja cijele zemlje, pa tako i Slavonije i Baranje. Ruralni turizam u kontinentalnom dijelu Hrvatske pokazuje, unatoč slabo razvijenim resursima, izniman razvojni potencijal (Ružić, 2009; Demonja 2014; Tubić, 2015; Leko-Šimić, 2007) koji je još uvijek u početnoj fazi razvoja ponude. Dosadašnja literatura više se bavila znanstvenim doprinosom obalnog podneblja, dok su istraživački potencijali unutrašnjosti Hrvatske ostali u drugom planu. U proteklom se desetljeću ta slika u znanosti, na što je zasigurno imao utjecaj i sve intenzivniji razvoj kontinentalnog turizma, ipak mijenja pa se javljaju novi znanstveni doprinosi ovoj temi.

\section{Klasteriziranje turističke ponude Slavonije}

Uspješno marketinško klasteriziranje turističke ponude istočne Hrvatske dugoročno bi trebalo rezultirati većom prepoznatljivošću Slavonije kao regionalnog klastera $\mathrm{s}$ osmišljenom marketinškom strategijom. Takav bi turistički klaster u sebi koncentrirao cjeloukupnu turističku ponudu Slavonije, Baranje (i Srijema) kao „kooperativnu 
djelatnost” različitih javnih, privatnih i civilnih dionika u turizmu. Ta strateška alijansa (Miočić Krce, Razović, Klarin, 2016) javnog, civilnog i privatnog sektora u turizmu sastoji se od turističkih zajednica, gospodarskih subjekata u hotelijerstvu, ugostiteljstvu, ali i mikro i srednjih poduzetničkih subjekata u seoskom/ruralnom turizmu. Pred turističkim je dionicima, nositeljima turizma, ipak još dugotrajni put s obzirom na to da se model upravljačke marketinške infrastrukture pretežito oslanja na turističke zajednice $u$ gradovima i općinama koje su uglavnom smještene u urban(iziran)im sredinama, a sela često nemaju nadležna tijela za upravljanje turizmom. Zato županijske turističke zajednice akumuliraju najveći marketinški potencijal jer kreiraju službenu razvojnu politiku pojedine destinacije. Turističke zajednice projiciraju identitet destinacije. Naglasak je na onim selektivnim prezentacijama turističke ponude koje se odvijaju na pretežito ruralnom području gdje turističkom ponudom upravljaju tamošnji subjekti kategorizirani kao javna i privatna tijela u turizmu. Potonji su objekti klasificirani kao subjekti s uslugom u agroturizmu i ugostiteljskom djelatnošću, obiteljska etno gospodarstva, odnosno seoska domaćinstva, kušaonice i ostali smještaj. Zato je važno uz sve ostale nositelje turističkog identiteta u Slavoniji i Baranji istaknuti ulogu i značaj seoskih domaćinstava i njihovu B2B komunikaciju.

S druge strane, javna operativna tijela su u ovom slučaju turističke zajednice, upravni odjeli lokalnih samouprava, a civilne inicijative okupljaju se u udrugama i zakladama u turizmu i socijalnom poduzetništvu. Moguća rješenja za razvoj ruralnog turizma treba tražiti u implementaciji adekvatnog modela upravljanja ovim osjetljivim područjem društvenog i ekonomskog razvoja te kvalitetnom operacionalizacijom na svim razinama. Pri tome je nužno unutarnje umrežavanje u internoj i eksternoj komunikaciji, a svi dionici, smatraju Krce Miočić i sur. (2016) trebaju sudjelovati u stvaranju idejnog „turističkog proizvoda”. Navedeni subjekti imaju ključnu upravljačku ulogu u odlučivanju koji su to direktni utjecajni atributi ruralne ponude koji diferenciraju ponudu od ostatka zemlje. Pojednostavljeno, ti su subjekti u službi destinacijskog menadžmenta. Na razini makroregije Slavonije i Baranje ta suradnička struktura upravljanja izvedena je na sljedeći način: 


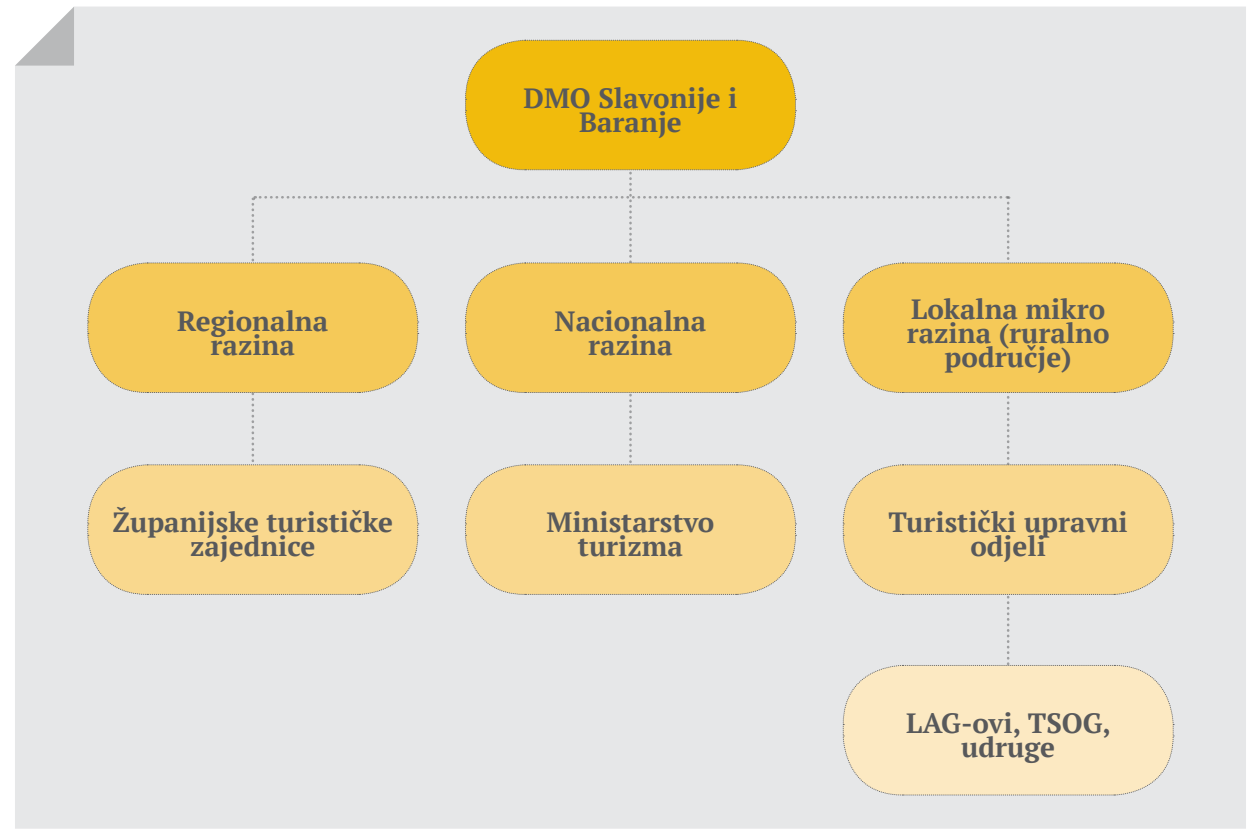

\section{Dizajniranje reputacije - malkroregija kao destinacijski brend}

U dizajnu i komunikaciji marketinškog sadržaja sudjeluju svi stakeholderi koji su prethodno definirani u "modelu utjecaja”. Dakle, lokalno stanovništvo uključeno u turizam (život i rad u etno-selima, organizacija tradicijskih festivala i manifestacija), registrirana seoska domaćinstva i ostali subjekti u agroturizmu - svi oni tvore najnižu razinu koja direktan kontakt ostvaruje kroz komunikaciju s gostima i posjetiteljima. Slijede turističke zajednice - organizacije koje upravljaju turističkom infrastrukturom, tijela strukovne uprave, i na najvišoj, upravljačkoj razini, jedinice lokalne samouprave (gradovi i županije). S obzirom da ruralni turizam makroregije Slavonije i Baranje svoje temelje uglavnom nalazi u nositeljima te razvojne funkcije - mini domaćinstvima, koje na kompetitivnom tržištu 
promoviraju turističke sadržaje umanjenim i rascjepkanim programima, a ne u lančanim i okrupnjenim hotelijerskim uslugama, zajednica počiva na ograničenim turističkim subjektima - malenim iznajmljivačima, pretežito obiteljskim gospodarstvima. Ne komuniciraju svi dionici isti sadržaj, što utječe na turističku percepciju identiteta i imidža regije. Najveći domet i kontrolu nad turističkim identitetom i promocijom prije su imale predstavničke organizacije, no fenomen interneta u svim društveno-tehnološkim sferama života ukazao je na drugačije stanje, a to je da arhitektura marketinškog dosega sada uključuje proširenu komunikaciju s lokalnim stanovništvom, civilnim organizacijama, privatnim iznajmljivačima, seoskim domaćinstvima i ostalima. Lokalno stanovništvo također ostvaruje interakciju s turistima (Canavan, 2016) i njihova percepcija mjesta može utjecati na iskustvo turista. Uspješno upravljanje destinacijom Slavonije i Baranje mora podjednako inkorporirati tri funkcije - normativnu, stratešku i operacionalizaciju te iste strategije. Na normativnoj razini poželjna destinacija kao gotov proizvod prema Magašu (1995) mora komunicirati jedinstven turistički koncept i ideju vodilju. Autori turističkog koncepta destinacije djeluju na nacionalnoj, a najviše na regionalnoj i lokalnoj razini. U brendiranju Slavonije i Baranje ispunjeni su neki elemetni normativne i operativne razine, no strateška je tek u početnom stadiju. Drugim riječima, otprilike se zna što se brendira, ali se ta misija ne provodi na svim društveno -gospodarskim razinama, već se direktno prelazi na online marketing.

Nadalje, nedostaje uspostavljena komunikacija o tome što se i kako i kome brendira, a nisu niti sve županije ravnomjerno turistički razvijene. Osječko-baranjska županija ovdje je po broju noćenja u 2018. godini najposjećenija, a po administrativnom smislu i najrazvijenja, na što zasigurno utječe činjenica što je središnja županija istočne Hrvatske, a na začelju su, po navedenim elementima (Rašić Bakarić, 2018) Virovitičko-podravska i, po broju noćenja, Požeško-slavonska županija. Međutim, sve županije u svojim turističkim planovima ističu ulogu u koordinaciji ruralnog turizma i daljnje unaprjeđenje tog dijela ponude. Premda ne nastupaju s istih pozicija, turističke zajednice i ostale organizacije $u$ novije vrijeme pokušavaju razviti cjelogodišnju ponudu.

Uspješna destinacija sadrži set atrakcija - razvijenu turističku infrastrukturu i stalnu dostupnost (Madden, Rashid,Zainol, 2016). Slavonija kao zaokružena turistička destinacija ima nekoliko identitetskih slojeva što se manifestira $u$ obliku multidimenzionalnog proizvoda. Čine ga glavni i sporedni elementi. Glavni atributi su odmor i aktivnosti u prirodi i na selu, što je značajna komponenta ekoturizma, zatim kuhinja i enoturizam 
(često se brendiraju zajedno) te cikloturizam. $\mathrm{U}$ ta se tri elementa ponude najviše ulaže i one se najbrže razvijaju u svih pet županija. Zatim slijede sporedne teme odnosno sporedni atributi ponude, a to su zdravstveni turizam te vjerski i kulturni turizam čiji veliki potencijali naginju pretakanju u glavnu skupinu atributa. Identifikacija glavnih i sporednih atributa nije dio strategije, već je sukreirana u susretu s turistom i povratnim informacijama. Zajedničke glavne karakteristike ruralnog turizma nalazimo u svih pet promatranih županija. Te karakteristike postaju asocijacije (atributi) i služe u opisivanju onoga što čini regionalni identitet destinacije.

Tablica 2. Vodeći atributi Slavonije i Baranje prema strateškim smjernicama HTZ-a i Ministarstva turizma (izradili autori)

\begin{tabular}{|c|c|c|c|}
\hline $\begin{array}{l}\text { Boravak na } \\
\text { selu }\end{array}$ & $\begin{array}{l}\text { Etnokulturni } \\
\text { turizam i baština }\end{array}$ & $\begin{array}{l}\text { Aktivni odmor } \\
\text { i rekreacija na } \\
\text { vodi }\end{array}$ & Enogastronomija \\
\hline Odmor u prirodi & $\begin{array}{l}\text { Etno-sela i ostavština, } \\
\text { multikuturalno okruženje }\end{array}$ & $\begin{array}{l}\text { Cikloturizam } \\
\text { (razvija se u svih } \\
\text { pet županija) }\end{array}$ & $\begin{array}{l}\text { Autohtona kuhinja } \\
\text { (kulen, švargl i dr.) }\end{array}$ \\
\hline $\begin{array}{l}\text { Autentični } \\
\text { doživljaj na selu, } \\
\text { etno-sela, pustare }\end{array}$ & $\begin{array}{l}\text { Tradicionalne manifestacije } \\
\text { i događaji (Đakovački } \\
\text { vezovi, Vinkovačke jeseni i } \\
\text { dr.), folklor }\end{array}$ & $\begin{array}{l}\text { Jahanje } \\
\text { (Đakovačka } \\
\text { ergela) }\end{array}$ & Graševina, kušaonice \\
\hline $\begin{array}{l}\text { Očuvana flora i } \\
\text { fauna (Kopački } \\
\text { rit, Papuk, parkovi } \\
\text { prirode) }\end{array}$ & $\begin{array}{l}\text { Povijesni i kulturni turizam } \\
\text { (dvorci, utvrde, sakralna } \\
\text { arhitektura) }\end{array}$ & $\begin{array}{l}\text { Sportovi na vodi, } \\
\text { lovni turizam }\end{array}$ & $\begin{array}{l}\text { OPG-ovi, eko } \\
\text { proizvodi }\end{array}$ \\
\hline
\end{tabular}

E-marketinški trendovi neprestano se mijenjaju i donose nove izazove u primjeni ICT tehnologije $\mathrm{u}$ turističkom sektoru, a „najbolji način promišljanja o upotrebi ICT-a u turističkoj industriji jest rasprava o samom turističkom proizvodu" (Morais i sur., 2016, str. 1382). Marketinški trendovi u suvremenom e-turizmu usmjereni su ka personalizaciji marketinških aktivnosti - broadcasting i narrowcasting tehnikama diseminacije komunikacije. Sve je popularnija i nova tehnologija proširene stvarnosti, virutalne ture, UGC i dr., a na „digitalno tržište” neprestano stižu inovativne platforme za putnike i domaćine.

Međutim, u objedinjavanju različitih marketinških koncepcija, upravljački subjekti $\mathrm{u}$ turizmu modele upravljanja nalaze $\mathrm{u}$ implementaciji i iznalaženju inovativnih 
e-marketinških alata jer je, „e-marketing integralni dio turizma, a e-turizam uključuje e-marketing” (Mousavi, 2012, str. 45). Upotreba informacijsko-komunikacijskih tehnologija (ICT) u turizmu odnosi se velikim djelom na prisutnost i aktivnosti u mrežnom marketingu, a „nove tehnologije omogućuju gospodarskim subjektima izravno povezivanje s potrošačima, stvarajući interakciju i odnose s njima” (Tubić, Bosnić, Kovačević, 2018, str. 332). U turizmu se, prema Fletcheru i sur. (2017), „utjecaj ICT-a očituje u turističkoj proizvodnji, marketingu, distribuciji i operativnoj funkciji privatnog i javnog sektora”, a posljedično i civilnog sektora. Sva tri sektora direktno i indirektno upravljaju DMO-om. Menadžment destinacije potporanj je snažnom regionalnom identitetu, čiji „turistički proizvod čine: prirodne atrakcije, posebne antropogene značajke, zanimljivi aktualni događaji, turistički objekti i turistička kultura” (Berc Radišić, 2009, str. 55).

Na središnjoj, odnosno glavnoj razini, to su službena turistička upravljačka tijela gdje su detektirani nedovoljno razvijeni digitalni marketinški alati u promociji destinacije i njenih materijalnih i nematerijalnih, nepokretnih i mobilnih znamenitosti i turističkih atrakcija. Većina turističkih zajednica na gradskoj i županijskoj razini nema zaokruženu strategiju djelovanja u određenom razdoblju što dodatno otežava turistički razvoj Slavonije. S te se kritičke pozicije otvaraju sljedeća pitanja: što i kako turistima komunicirati određeni proizvod ili destinaciju ako nemamo jedinstvenu marketinšku strategiju koja se temelji na prethodno valoriziranim identitetskim oznakama na čijoj izgradnji i prepoznatljivosti svi involvirani trebaju ustrajati?

S obzirom na recentna istraživanja ostalih hrvatskih regija poput Istre gdje su pokazatelji uspješnog turističkog brendiranja normirani pod konceptualnim nazivnikom tzv. „umbrella brendiranja”, isto to suplementira se u govoru o brendiranju regije Slavonije. Ti se odgovori trebaju tražiti top down pristupom gdje su na vrhu hijerarhijske piramide javna tijela, pa civilna i na koncu mikro - turistički subjekti u privatnom sektoru. Svi oni, bilo da dolaze iz javnog ili privatnog sektora, (dvosmjerno) komuniciraju svoje sadržaje na internetu kroz različite kanale - službene internetske domene, društvene mreže, blogove i specijalizirane mrežne platforme za promociju ruralne destinacije. Svatko od pružatelja usluga, od Turističke zajednice pa do agroturističkih objekata, komunicira ono što smatra atributima destinacije čije sadržaje potencijalni turist ima za posjetiti. Online iliti e-marketing neke destinacije odvija se kao višefazni proces - u slučaju Slavonije detektirane su opisne sastavnice, odnosno jedinstvene osobine mjesta prema smjernicama HTZ-a, a kreću se u rasponu od posebnosti prirodnog okoliša (ravničarski 
zavičaj idealan za aktivni odmor $\mathrm{u}$ obliku cikloturizma), do etnokulturnih posebnosti kao što su autohtona tradicionalna hrana i vinska kultura s bogatih vinogorja. U skladu s dostupnim digitalnim alatima na internetskoj platformi, nositelji turizma osmišljavaju i plasiraju konačni proizvod. Pošiljatelj informacije stvara brend istovremeno usmjeravajući komunikaciju i doseg poruke.

\subsection{Upravljanje e-marketingom Slavonije}

U Hrvatskoj se e-turizam ne razvija strateški, već ovisi o trendovima i pojavama na globalnom internetskom tržištu. Nositelji funkcije upravljanja ruralnim turizmom u Slavoniji u marketinškim nastojanjima posežu za novim tehnologijama. Proces identifikacije onoga što konkretno nudi ovakav oblik turizma generiraju Turističke zajednice koje imaju ključnu ulogu u umrežavanju svih dionika u ruralnom turizmu. Svi su, na čelu s TZ-om, uključeni u „brend u nastajanju”. Bolfek i suradnici (2014) navode da je ključna uloga u oblikovanju identiteta ruralnog područja istočne Hrvatske, prema provedenim istraživanjima, pozicioniranje kao odredišta očuvane prirode, tradicije te bogate gastro ponude, uz vina u tradicionalnim kušaonicama i na sajmovima. Takav način „pripovijedanja turističkog identiteta” može biti dio komunikacijske strategije na svim razinama komuniciranja informacije, tj. poruke, ne samo u digitalnom obliku. Kojim konkretnim „ključnim marketinškim tehnikama” subjekti komuniciraju izabrane elemente brenda koje čine set povezanih i prethodno određenih asocijacija, ostaje na odluci odgovornih posrednika u toj komunikaciji - tijela javne uprave. Te „pojmovne konstrukcije” dio su identitetskog dizajna destinacije i inherentna su podloga svakom turističkom doživljaju i komuniciraju se na internetskim stranicama, blogovima, na najpopularnijim društvenim mrežama - Facebooku, Instagramu i dr., putem mobilnih aplikacija, e-bookinga i specijaliziranih e-kanala. Slavonija je do sada bila promovirana kao regija čije se mini destinacije mahom nalaze u prirodi, gdje se uživa u etno-ponudi tradiciji i običajima, bilo da je riječ o domaćoj gastro i eno-ponudi ili drugim sadržajima. Marketing upućen na iskustvo i doživljaj ovdje pomaže osnaživanje navedenih elemenata turističke ponude. 


\subsection{Internet i turizam}

Internet je najbrže rastući način upotrebe marketinga u turizmu, dostupan svima - i malim i velikim turističkim djelatnicima, na svim organizacijskim razinama u turističkoj (ne)profitnoj organizaciji. Ipak, službene internetske domene zbog traženih znanja, financijske strukture i neprestanog održavanja isplativije su i mahom očekivanije $u$ programu javnih i civilnih udruga, nego li u programu privatnih pružatelja turističkih usluga. Turističke zajednice u Slavoniji, Baranji i Srijemu i druga javna turistička tijela uglavnom komuniciraju preko službenih internetskih stranica koje im, među ostalim, služe i kao e-marketinški alati i komunikacijsko-relacijski načini pristupa poveznicama ostalih turističkih subjekata. Seoska se domaćinstva uglavnom služe drugim digitalnim platformama i alatima, povoljnijim rješenjima - društvenim mrežama, javnim servisima za rezervaciju smještaja, blogovima i ostalim načinima promocije svojih ugostiteljskosmještajnih usluga.

Tablica 3. Kategorizacija internetskih alata u marketinške svrhe (izradili autori)

\begin{tabular}{|c|c|c|c|}
\hline $\begin{array}{l}\text { Internetske } \\
\text { stranice }\end{array}$ & $\begin{array}{l}\text { Društvene } \\
\text { mreže }\end{array}$ & Portali & $\begin{array}{c}\text { Internetske } \\
\text { aplikacije }\end{array}$ \\
\hline Javne organizacije & Facebook & TripAdvisor & Crotune \\
\hline $\begin{array}{l}\text { Komercijalni subjekti } \\
\text { (smještajni objekti) }\end{array}$ & Instagram & Airbnb, Booking & $\begin{array}{l}\text { Regional Vision One, } \\
\text { (OBŽ), Panonia Tour } \\
\text { (PSŽ) }\end{array}$ \\
\hline Civilne organizacije & Twitter & Ruralna.hr & $\begin{array}{l}\text { Aplikacije } \\
\text { Moj-seoski.hr }\end{array}$ \\
\hline
\end{tabular}

Empirijsko istraživanje u obliku dizajniranog online upitnika na temu uloge e-marketinga u ruralnom turizmu Slavonije i Baranje, provedeno je u srpnju i kolovozu 2019. godine. Istraživanjem je obuhvaćeno svih pet slavonskih županija. Istraživačka pitanja koja su potaknula istraživanje postavljena su na temelju problematike marketinške strategije i komuniciranja subjekata ruralnog turizma $u$ vidu njihovog korištenja i implementacije e-marketinških alata: (1) U kojim je elementima, prema mišljenju nositelja ruralnog turističkog razvoja i usluge, sadržan jedinstveni turistički brend Slavonije i Baranje?; (2) Na koji se način korištenjem e-marketinških alata može objediniti jedinstvena turistička 
ponuda destinacije Slavonije i Baranje?; te (3) Što, po mišljenju nositelja ruralne turističke ponude i razvoja, trebamo komunicirati na tržište, a da čini jedinstveni brend regije?

\subsection{Metodologija istraživanja}

Online upitnik sadrži 17 pitanja koja su poslana na službene e-adrese nositelja ruralnog turizma u Slavoniji (radi preglednosti svih pet slavonskih županija ubuduće će se brendirati ne po svojim administrativno-prostornim granicama, već kao brend Slavonija), a poslan je svima koji su prisutni na internetskim stranicama turističkih zajednica, budući da su promatrani kao prigodan uzorak za cilj istraživanja. Ankete su poslane na 90 e-adresa nositeljima ruralnog turizmu iz javnog, građanskog i privatnog sektora od čega je dobiveno 27 odgovora, što čini stopu odgovora od 30\%. Pitanjima se ciljalo na aktivne sudionike turističke industrije Slavonije, Baranje i Srijema - prvenstveno na osobe koje u poslovnoj piramidi mogu učiniti konkretne poteze u mijenjanju krvne slike turističkog sektora, a to su vlasnici, direktori i rukovoditelji poslovanja (srednji i top mendžment). Što se može isčitati iz dobivenih rezultata i kakav sve potencijal skriva Slavonija i Baranja, kako ju uopće percicpiraju nositelji ruralnog turizma, što komuniciraju, vide li potrebu za zajedničkom strategijom i potencijal u e-marketingu, prikazujemo u nastavku.

\subsection{Rezultati istraživanja}

Većina ispitanika pripada Osječko-baranjskoj županiji (40,7\%) zatim slijede Vukovarskosrijemska i Brodsko-posavska u jednakom postotku (18,5\%), Virovitičko-podravska $(14,8 \%)$ te Požeško-slavonska županija $(7,4 \%)$.

Najviše ispitanika pripada privatnom sektoru (obiteljska poljoprivredna gospodarstva, seoska domaćinstva, privatno poduzetništvo), zatim javnom sektoru (kulturne ustanove, muzeji, turističke zajednice), a najmanje ispitanika pripada organizacijama civilnog društva (udruge). 


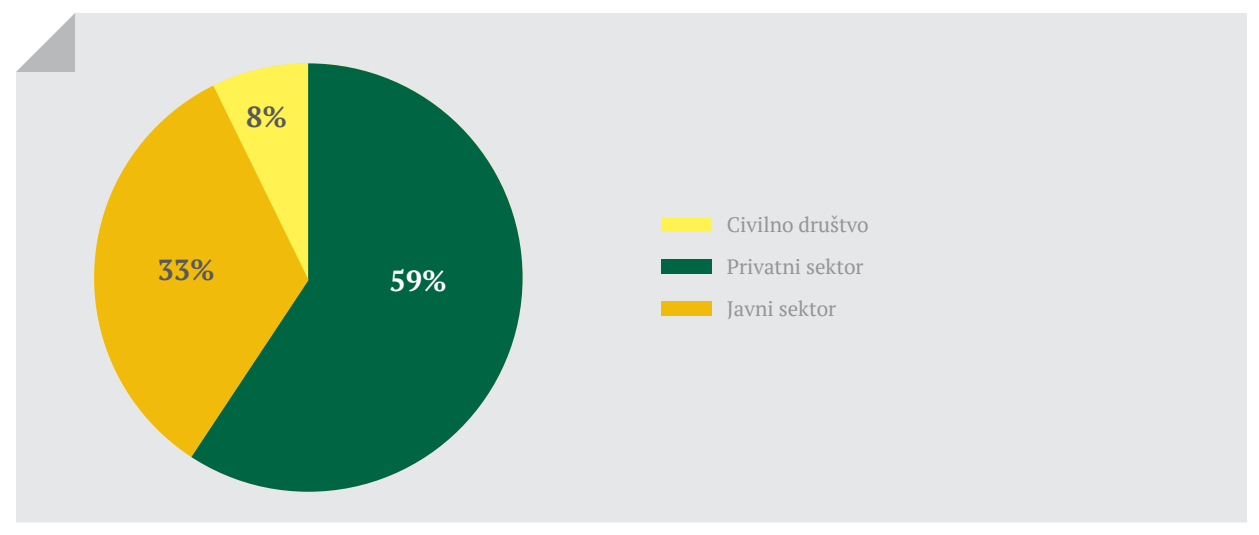

Grafikon 1. Pripadnost ispitanika u sektoru turizma

Iako je cilj rada bio ispitati što veći broj vodećih ličnosti ciljanih organizacija, što je i naglašeno $u$ uputama za ispunjavanje upitnika, ipak je najveći postotak odgovora stigao iz nižih sektora poslovne piramide - njih $48,1 \%$ odgovorilo je da pripadaju kategoriji „ostalo”, uz ponuđene odgovore pripadnosti hijerarhijskoj strukturi koja uključuje i visoki menadžment, menadžment prodaje te vlasničku poziciju. 33\% ispitanika se izjasnilo kao vlasnici turističkih subjekata. Menadžment prodaje i visoki menadžment na istraživanje su reagirali u najmanjem postotku - $11 \%$ visokog menadžmenta i $7 \%$ menadžera prodaje.

Poslovanje ispitanih subjekata uglavnom pripada vremenskoj kategoriji poslovanja od 0 do 5 godina (30\%) te preko 16 godina (30\%), dok $26 \%$ subjekata posluje između 6 i 10 godina. Uslugu smještaja nudi $59 \%$ ispitanih subjekata, što podsjeća na realne statistike kada se govori o pružateljima smještaja i nedostatku smještajnih kapaciteta na području Slavonije i Baranje, a koji čine jednu od glavnih predispozicija za privlačenje većih turističkih grupa na naše područje jer se radi o jednom o bazičnih uvjeta, uz koje potom dolazi pitanje hrane - generalno gledano: pitanje pružanja usluge polupansiona, odnosno punog pansiona. U posljednje vrijeme raste broj smještajnih kapaciteta u regiji te je sve veća potražnja za istima.

\subsection{Percepcija turističkog pozicioniranja Slavonije u odnosu na druge regije $\mathrm{u} \mathrm{RH}$}

Kako je prethodno istaknuto, rezultati istraživanja pokazali su da postoje vrijednosti koje nositelji ruralnog turizma u Slavoniji, Baranji i Srijemu prepoznaju kao specifične, 
međutim nedostatak komunikacijske i marketinške strategije stavlja izazov pred pojedince i organizacije $u$ vidu revizije već postavljenih temelja turističke ponude Slavonije, na način da se prirodni atributi ojačaju putem digitalnih kanala. Pozitivan odgovor u iznosu od $89 \%$ na zatvoreno pitanje ima li Slavonija jedistvenu turističku ponudu u odnosu na druge regije u RH, ukazuje na percpeciju dionika turizma da postoji turistički doživljaj Slavonije i Baranje koji se doživljava kao jedinstven što ga može učiniti nezaboravnim. Drugim riječima, svjesnost o atributima postoji te je sljedeći korak predočiti ciljanim skupinama njegovu vrijednost.

Geostrateška je pozicija Slavonije prirodna inspiracija oblikovanju strategije turizma i temelji se na amalgamu različitih selektivnih oblika turizma, od enogastro ponude, domaće kuhinje i vinskog turizma, odmora u prirodi pa do interaktivne prezentacije kulturno-povijesne baštine i lokalnih običaja. Naši su se ispitanici kroz pitanje o vrijednostima koje Slavonija ima naspram drugih regija većinom složili da je osnovna prednost, odnosno jedinstvena turistička ponuda koja nas može povesti ka konkretnim rezultatima, svakako ponuda eko proizvoda te naglasak na domaćem i tradicionalnom predstavljanju turističkog proizvoda. To znači da su sve odrednice koje slijede nakon toga, a obuhvaćaju odmor, opuštanje i mir, gastro ponudu pa sve do eno turizma i cikloturizma koje ispitanici manje ističu kao jedinstvene u odnosu na druge regije u Hrvatskoj, zapravo samo izdanci glavne ideje temeljene na jednoj riječi - tradicijsko.

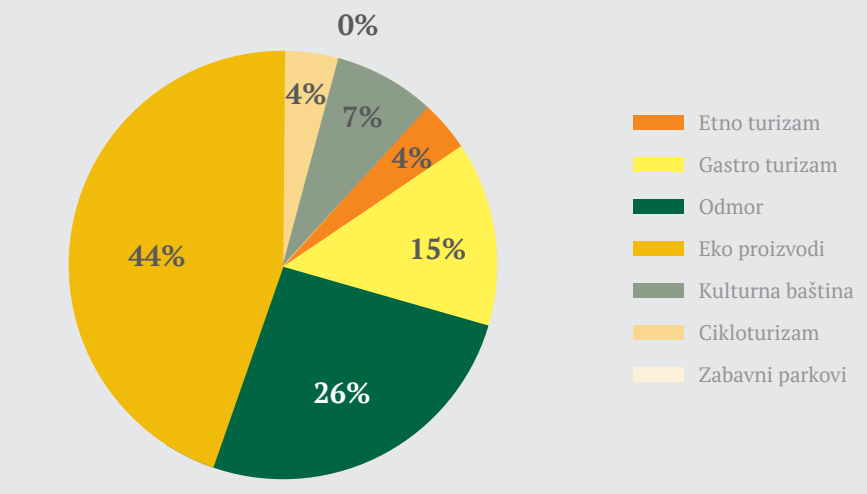

Grafikon 2. Jedinstvena ponuda Slavonije u odnosu na druge regije u Hrvatskoj 
U vremenu hiperkonzumerizma i brzog kapitalizma, sačuvati vrijeme za užitak, sačuvati stare vrijednosti od zaborava, oživjeti osjete vida, sluha, dodira, okusa i njuha na hedonistički i humanistički način, u smislu da nam spomenuti ne služe za održavanje organizma $u$ radnoj funkciji, nego da nam ti isti služe u svrhu preispitivanja životnih vrijednosti, svakako je vrijednost koja se može istaknuti u percepciji turističke jedinstvenosti i posebnosti Slavonije. U simulakrumu stvari i pojava 21. stoljeća, Slavonija se može istaknuti ne svojom različitošću, nego istošću s prirodom, a što ukazuje na visok potencijal turističke ponude, $\mathrm{s}$ obzirom na rastuće trendove turista $\mathrm{u}$ vidu odmora $\mathrm{u}$ prirodi i na selu.

Analizom upitnika nametnulo se nekoliko bitnih zaključaka potrebnih za dizajn i razvoj infrastrukture $u$ izgradnji digitalne priče o turizmu Slavonije. Iskristalizirale su se aktivnosti na koje se regija može fokusirati, a s ciljem što boljeg lociranja ciljanih skupina i izrade strateškog plana s aktivnostima i ponudama namijenjenih uspješnom privlačenju spomenutih. Ono što je optimistično jest činjenica da su ispitanici, od ponuđenih sastavnica ruralnog turizma Slavonije, Baranje i Srijema, sve navedene ocijenili kao gotovo jednako privlačnima potencijalnim posjetiteljima (mogućnost više odgovora): odmor u prirodi, tradicijski ugođaj, gastro i eno ponudu te kulturno-povijesnu baštinu istaknulo je preko $80 \%$ ispitanika, dok su se manje složili oko jedinstvenosti sportsko-zabavnih aktivnosti (14\%). S jedne strane, takav zaključak olakšava posao u odabiru aktivnosti pri promociji Slavonije budući da je ustanovljena lepeza vrijednosti koje se mogu prezentirati kao jedinstvena ponuda, a s druge strane, postoji opasnost od razrjeđivanja pojedine vrijednosti do razine nezanimljivosti i neatraktivnosti ciljanoj publici. Na koji način istost prezentirati u virtualnom svijetu, iskazat će se analizom dobivenih rezultata i prelaskom na glavni dio i osnovnu temu našega rada - koja je uloga e-marketinga u ruralnom turizmu Slavonije, kakav stav ispitanici imaju o toj platformi u vidu marketinških potencijala i aktivnosti te promoviranja vrijednosti koje su i sami istaknuli i prepoznali.

Upravo iz tog razloga i zbog sadržaja i atributa koje promatrana destinacija nudi $u$ turističkoj ponudi, a koji su navedeni u upitniku i također podjednako ocijenjeni, $s$ posebnim naglaskom na prirodna bogatstva kao korijen priče za digitalne platforme, prepoznaje se potreba i želja ispitanika za uključivanjem e-marketinga u definiranju puta ka brendiranju Slavonije kao perjanice kontinentalnog turizma.

Da bi brendiranje i pozicioniranje na tržištu bilo konkurentno, zanimalo nas je koliko su ispitanici upućeni u mjere ili strategije suradnje privatnog i javnog sektora s ciljem povećanja turističkih aktivnosti Slavonije. 52\% ispitanika upoznata su sa strategijama 
ili mjerama partnerstava/suradnji, dok ih čak $85 \%$ tvrdi da im nedostaje strategija zajedničkog djelovanja i komunikacije, što ukazuje da unatoč postojećim mjerama koje su poznate, nije riješeno pitanje suradnje niti delegiranja aktivnosti u strategiji brendiranja i aktivnosti.

\subsection{Digitalni marketing}

\subsubsection{Prisutnost i komunikacija na e-marketinškim platformama}

S obzirom na percpeciju dionika turizma o turističkom potencijalu ruralne Slavonije, cilj istraživanja bio je vidjeti što i kako isti komuniciraju putem e-marketinških alata na kojima su prisutni te kako percipiraju te pogodnosti u vidu razvijanja i promocije turističkih sadržaja. Saznanje do kojega smo došli ovim istraživanjem iskoristit ćemo u specifičnu svrhu - otkrivanju potencijala digitalnog marketinga u korist promocije kontinentalnog turizma na području Slavonije.

Svi ispitanici prisutni su na Facebooku (100\%), Instagram koristi 55\%, Booking 41\%, Airbnb 30\%, e-mail marketingom se koristi 22\%, na LinkedIN mreži nije nitko prisutan, a čak 74\% ispitanika ima svoju internetsku stranicu. Od 21 ključne riječi koje smo ponudili ispitanicima da odaberu koje od njih koriste $u$ komunikaciji na digitalnim plaftormama, prikazujemo što komunicira više od polovice. U objavama, oglasima i reklamama najčešće koriste riječi: priroda (93\%), domaće (74\%), opuštanje (70\%), gastro ponuda, gostoljubivost i netaknuta priroda (56\%) te tradicionalno (52\%).

\subsubsection{Percepcija digitalnih platformi kao marketinških alata}

Da komunikaciju na digitalnim kanalima rade sami istaknulo je $89 \%$ ispitanika, a $11 \%$ je angažiralo vanjskog suradnika ili agenciju. Ispitanike koji e-marketing rade sami, pitali smo zašto tako pristupaju ovom marketinškom kanalu i koji je uzrok tomu. U tom segmentu ispitanici najveći problem vide u cijeni. Njih 67\% smatra kako je cijena vanjskih suradnika ili agencija glavni uzrok što ih ne angažiraju, dok njih 29\% smatra kako e-marketing mogu uspješno odraditi sami, a $4 \%$ iskazalo je da je zarada premalena da bi se moglo uložiti u taj segment. 


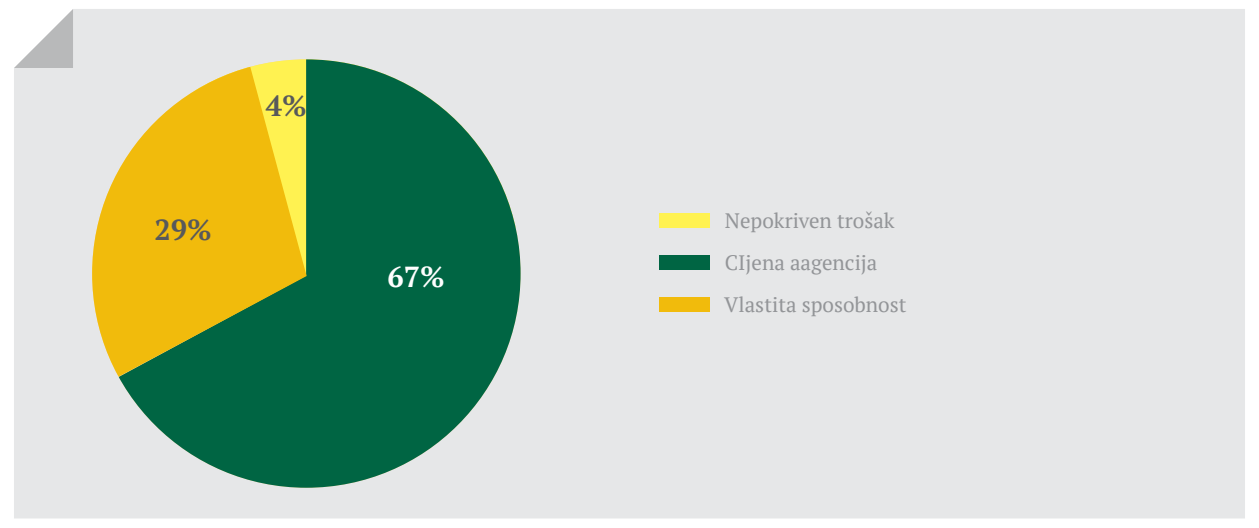

Grafikon 3. Uzroci neangažiranja suradnika ili agencija za e-marketing

Ispitanici se slažu da je pristutnost na digitalnim platformama jako važna $(77,8 \%)$ jer pomaže njihovom poslovanju u smislu donošenja više posjetitelja (74\% posto se slaže $s$ tom činjenicom). Disperziranije odgovore dobili smo na pitanje jesu li digitalne platforme korisne za privlačenje ciljane skupine - 59\% se u potpunosti slaže, $30 \%$ se slaže, $7 \%$ niti se slaže niti se ne slaže, a 4\% se ne slaže, što navodi na razmatranje o promjeni sadržaja ili načina oglašavanja te točno ciljanje skupina putem digitalnih kanala, što nismo ovim istraživanjem obuhvatili, u smislu znanja i ulaganja u vidu plaćenih oglasa na digitalnim kanalima. Na tragu ovog odgovora, $41 \%$ ispitanika se u potpunosti slaže da im se povećao promet ili posjećenost otkad koriste digitalne platforme, 30 posto se slaže, $26 \%$ se niti slaže niti ne slaže, a $4 \%$ se ne slaže.

Budući da smo dobili podatak o tome angažiraju li vanjske suradnike ili se digitalnim platformama bave sami i razloge zašto je tako, postavili smo tvrdnju da za komuniciranje i oglašavanje na digitalnim platformama ne moraš biti marketinški stručnjak, nego samo informatički pismen. Rezultati su pokazali da se s tom tvrdnjom u potpunosti slaže $26 \%$ ispitanika, $15 \%$ se slaže, $37 \%$ se niti slaže niti ne slaže, a $22 \%$ se ne slaže. Ovi nam podaci daju jasniju sliku o percepciji digitalnih kanala kao marketinških alata.

Iz navedenoga možemo zaključiti da nositelji ruralnog turizma Slavonije prepoznaju važnost komuniciranja i prisutnosti na e-platformama, kroz podatke o povećanju prodaje ili posjećenosti, međutim, nedovoljno da bi angažirali agencije ili vanjska lica da obavljaju taj posao jer ga smatraju nastavkom na postojeće informatičko znanje. 
Kroz prizmu znanja i tehnika koje se mogu koristiti u e-marketingu, ovo se može promatrati kao nedovoljno ulaganje u strategiju e-marketing dimenzije. U digitalnoj sferi, može se promatrati kao dobrovoljni odlazak s konkurentnog tržišta.

Temeljem ovih odgovara otvaraju se nova pitanja, odnosno percpecija nositelja turizma za koirštenje e-marketinških usluga i znanja potrebnih za obavljanje istih. S obzirom na visok postotak vlastita rada na mrežama, čini se da je percpecija o e-marketinškim strategijama i tehnikama prilično negativna. Uzmemo li također u obzir da je ključni faktor za angažiranje vanjskih suradnika cijena i marketinški koncept koji se pokazao koristan - financijsko ulaganje u stručan i pomno isplaniran e-marketing koje podiže turističkog subjeka, čime se konkretni rezultati mjere alatima, što na koncu opravdava financijsko ulaganje kroz povećane angažmane prodaje. U ovom segmentu možemo zaključiti da je nužna edukacija nositelja ruralnog turizma u vidu e-marketinških usluga.

\section{Zaključak}

Upravljanje ruralnim turizmom u Slavoniji još uvijek nije obuhvaćeno konkretnom regionalnom strategijom, već se mahom oslanja na partikularne turističke interese i znanja lokalnih zajednica, turističkih agencija, seoskih domaćinstava, a koji u javno-privatnom partnerstvu s turističkim zajednicama i uz povremenu asistenciju udruga civilnih građana djeluju u osmišljavanju koherentne i postojane turističke pojave. Strategija treba naglasiti široko sudjelovanje u e-marketingu i aktivnostima društvenih medija kako bi se ostvarile koristi destinacijskog menadžmenta na svim organizacijskim razinama upravljanja ruralnim turizmom u istočnom dijelu Hrvatske. Online prisutnost ključan je čimbenik u percepciji destinacije, a internet pritom postaje najvažniji komunikacijski kanal jer se turistu tako komuniciraju pažljivo oblikovani sadržaji i informacije o onome što turistički posjet nudi. Ispitivanje upravljanja e-marketingom u online promociji ruralnog turizma na istoku Republike Hrvatske dovodi do zaključka kako se Slavonija, Baranja i Srijem nalaze pred izazovima u procesu razumijevanja identiteta destinacije iz perspektive dionika do konačne strategije brendiranja. Nositelji ruralnog turizma prepoznaju važnost komunikacije u vidu promoviranja vlastitih sadržaja i ponuda. Ovim istraživanjem utvrđeno je da smatraju i da postoje posebnosti u regiji koje su specifične u odnosu na ostatak države, međutim, nedostaje jasna percepcija i strategija komunikacije kroz koju bi se promovirale utvrđene vrijednosti. E-marketing ispitanici percipiraju kao dodatni 
marketinški alat postojećim kanalima, kojim mogu sami upravljati, a donosi im generalno dobre rezultate vidljive kroz poslovanje. Do sada je svaka županija prethodno razvijala submarketinšku koncepciju, a njih je nužno iznivelirati u jedan marketinški splet i tako u budućnosti horizontalnim povezivanjem nastaviti razvijati stare i nove elemente na razini svih pet slavonskih županija. Ova regija je neupitan potencijal kojemu nedostaje strateški plan i koja bi, brendiranjem i povećanjem vidljivosti na tržištu, doživjela kulturološku i ekonomsku obnovu te razvila turistički doživljaj kao jedinstveno iskustvo u kontinentalnom turizmu Republike Hrvatske.

\section{Literatura}

- Andrlić, B. (2007). Primjena e-marketinga u turizmu. Poslovna izvrsnost, 1 (2), 85-97.

- Buhalis, D. (2003). E-Tourism: Information Technology for Strategic. Tourism Management. Cambridge: Pearson.

- Bolfek, B., Jakičić, D., Lončarić, B. (2014). Utjecaj marketinga na razvoj turističkog brenda Slavonije i Baranje. Ekonomska misao i praksa, 1, 247-276.

- Bolfek, B., Lončarić, B. (2013). Mogućnosti razvoja turizma na ruralnom području Brodsko-posavske županije. Oeconomica Jadertina, 3 (1), 73-8.

- Canavan, B. (2014). Sustainable tourism: development, decline and de-growth. Management issues from the Isle of Man. Journal of Sustainable Tourism, 22 (1), 127-147.

- Demonja, D., Ružić, P. (2010). Ruralni turizam u Hrvatskoj. Zagreb: Meridijani.

- Demonja, D. (2014). Pregled i analiza stanja ruralnog turizma u Hrvatskoj. Sociologija i prostor: časopis za istraživanje prostornoga i sociokulturnog razvoja, 52 (1), 69-97.

- Fletcher, J., Fyall, A., Gilbert, D., Wanhill, S. (2017). Tourism: Principles and Practice. Essex, UK: Pearson Education.

- Leko Šimić, M., Čarapić, H. (2007). Agroturizam u istočnoj Hrvatskoj: model razvoja i prilagodba novom tržišnom segment. Perspektive razvoja ruralnog turizma (str. 1-9). Hvar.

- Madden, K., Rashid, B. Zainol, N. A. (2016). Beyond the motivation theory of destination image. Tourism and hospitality management, 22 (2), 247-264.

- Magaš, D. (1995). Strategija razvoja turističke destinacije. Tourism and hospitality management, 1 (1), 139-143.

- Miočić, Krce, B., Razovič, M., Klarin, T. (2016). Management of sustainable tourism destination through stakeholder cooperation. Management, 21 (2), 99-120.

- Morais, E. P., Sousa, J. P., Cunha R. C., Santos, A. (2016). Information and Communication Technologies in Tourism: Challenges and Trends innovation Management and Education Excellence Vision 2020 (str. 1381-1387I. Dostupno na: https://www. researchgate.net/publication/316830871_Information_and_communication_technologies_in_tourism_Challenges_and_trends. Pristupljeno 22. srpnja 2019.

- O’Connor, P. (1999). Electronic information distribution in tourism and hospitality. Wallingford: CAB International.

- Rašić Bakarić, Ivana. (2018). Sektorske analize. Dostupno na: https://www.eizg.hr/userdocsimages/publikacije/serijskepublikacije/sektorske-analize/SA_turizam_studeni_2018.pdf. Pristupljeno 21. lipnja 2019.

- Tubić, D. (2015). Model razvoja ruralnog turizma kontinentalne Hrvatske (doktorska disertacija). Osijek: Ekonomski fakultet Sveučilišta u Osijeku.

- Tubić, D., Bosnić, I., Kovačević, M. (2018). E-marketing u funkciji razvoja ruralnog turizam: Slučaj Slavonije, Baranje i Srijema. U: Smolčić Jurdana, D., Milohnić, I. (ur.), Zbornik radova s 4. međunarodnog kongresa o ruralnom turizmu (str. 329337). Opatija: Sveučilište u Rijeci, Fakultet za menadžment u turizmu i ugostiteljstvu. 


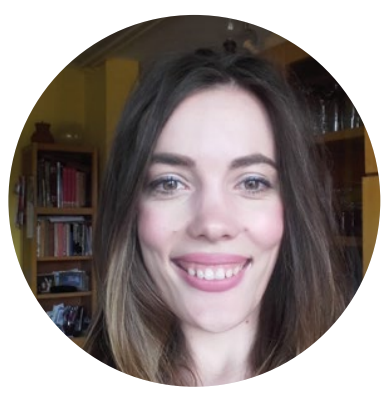

\section{Marija Završki}

Marija Završki has a Master's degree in Cultural Studies. During her studies, she was awarded the Rector's Award for the best seminar paper. The paper dealt with by contemporary women's writing in Croatian literature. Since 2017 she works as a journalist on the Informative program of the Television of Slavonia and Baranya in Osijek. In 2016/2017 she enrolled in postgraduate study program of Cultural Studies and Communication at The Doctoral School of the University of Osijek. The scientific field of Marija's interest is marketing, heritage studies and cultural tourism. She is a member of Matica hrvatska in Osijek, alumni club of students of Cultural Studies, and a platform for youth called "Mladforma". She presented her research on various local and international scientific conferences and seminars.

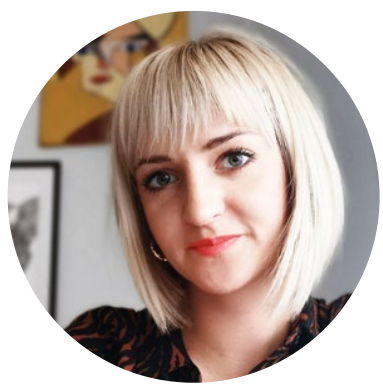

\section{Katarina Horvat}

Katarina Horvat graduated at the Department of Cultural Studies at in 2015 at J. J. Strossmayer University of Osijek with recognition for the best student in the Media Culture course. Currently she is a $\mathrm{PhD}$ Student at Doctoral School at the same university in the field of communication and information sciences. Since 2013 Katarina has participated in several international conferences with a few published scientific and professional papers. Katarina participated in various programs of non-formal education, including human rights projects, Erasmus + programmes and courses for developing communication and business skills. She is the owner of HORKA communications - PR manager, organizer and lecturer of several media literacy projects, event manager, producer of videos and short films and trainer of public speaking. Currently she is attending the London School of

Public Relations in Croatia. 